\title{
Simvastatin Action Is Not Related to HDAC2 Expression in Non-Small Cell Lung Cancer (NSCLC)
}

\author{
Gallelli Luca', Falcone Daniela1, Perri Mariarita' ${ }^{2}$, Erika Cione², Pelaia Girolamo', \\ Mesuraca Maria ${ }^{3}$, Terracciano Rosa1, Spaziano Giuseppe ${ }^{4}$, D'Agostino Bruno $^{4 *}$, \\ Navarra Michele ${ }^{5}$, Savino Rocco ${ }^{1}$ \\ ${ }^{1}$ Department of Health Science, University of Catanzaro, Catanzaro, Italy \\ ${ }^{2}$ Department of Pharmacy, Health and Nutritional Science, University of Calabria, Cosenza, Italy \\ ${ }^{3}$ Department of Medical and Surgical Sciences, University of Catanzaro, Catanzaro, Italy \\ ${ }^{4}$ Department of Experimental Medicine, School of Medicine, Second University of Naples, Naples, Italy \\ ${ }^{5}$ Department of Drug Sciences and Health Products, University of Messina, Messina, Italy \\ Email: ^bruno.dagostino@unina2.it
}

How to cite this paper: Luca, G., Daniela, F., Mariarita, P., Cione, E., Girolamo, P., Maria, M., Rosa, T., Giuseppe, S., Bruno, D’A., Michele, N. and Rocco, S. (2016) Simvastatin Action Is Not Related to HDAC2 Expression in Non-Small Cell Lung Cancer (NSCLC). Journal of Cancer Therapy, 7, 939-952. http://dx.doi.org/10.4236/jct.2016.712091

Received: May 24, 2016

Accepted: November 14, 2016

Published: November 17, 2016

Copyright $\odot 2016$ by authors and Scientific Research Publishing Inc. This work is licensed under the Creative Commons Attribution International License (CC BY 4.0).

http://creativecommons.org/licenses/by/4.0/

(c) †) Open Access

\begin{abstract}
In this study, we lowered the expression of HDAC2 protein, to evaluate the effects of simvastatin on the biochemical pathways involved in inflammatory and metastatic response. The model used is the non-small cell lung cancer line (GLC-82). Trypan blue staining for assessing vital cell number to be seed and MTT assay was used as cell proliferation test. Lentivus for HDAC2 was used to silence its mRNA. Western blotting analysis was used for protein extracts, and ELISA was done on culture media for cytokines (IL-6, IL-8 and TNF-alpha) release. Hydrogen peroxide $\left(\mathrm{H}_{2} \mathrm{O}_{2}\right)$ was used to induce oxidative stress. Our results have shown that Lentivirus containing the shHDAC2 in GLC-82 cells was able to reduce protein expression of HDAC2. In the GLCshHDAC2 cell line obtained, $\mathrm{H}_{2} \mathrm{O}_{2}$ induced a significant increase in cytokines release and ERK1/2 phosphorylation $(\mathrm{P}<0.01)$; a significant decrease of RECK activation $(\mathrm{P}<0.01)$; a significant increased activation $(\mathrm{P}<0.01)$ of both MMP-2 and MMP-9 and an increased activation of NF- $\kappa$ B, MyD88, TRAF-6, TRADD, TRAF-2. In GLCshHDAC2 cell, the treatment with simvastatin $(30 \mu \mathrm{M})$, significantly affected all the biochemical markers examinated $(\mathrm{P}<0.01)$. In conclusion, from our report emerge, that simvastatin is able per se to inhibit oxidative stress in lung cancer cells, overcoming HDAC2 expression.
\end{abstract}

\section{Keywords}

Lung Adenocarcinoma Cells, HDAC2, Statins, Cell Proliferation, Cytokines 


\section{Introduction}

There are two major types of lung cancer: Small Cell Lung Cancer (SCLC) and NonSmall Cell Lung Cancer (NSCLC). This latter type of lung cancer has an incidence of about $85 \%$ worldwide [1]. The multifactorial nature of NSCLC did not give yet a clear understanding of the molecular mechanisms, involved in its development [2]. It has been recognized that histone deacetylases (HDACs) play an important role in bronchoconstriction, airway inflammation and cancer development [3] [4]. In fact, recently HDACs inhibitors are used in clinical trials in many types of cancer. The biochemical feature of HDACs enzymes is removal acetyl groups from $\mathrm{N}$-acetyl lysine amino acid proteins residue. Those enzymes have been also reported to play a role in both inflammation and metastasis modulating NF- $\kappa \mathrm{B}$ and matrix metalloprotinases (MMPs) pathways [5] [6] [7]. In particular, NF- $\kappa$ B activated by tumour necrosis factor-alpha (TNF- $\alpha$ ) induces the activation of inflammatory proteins, e.g. myeloid differentiation (MyD) marker MyD88, as well as the secretion of several cytokines (e.g. TNF, Interleukin-1 (IL-1), IL-6, IL-8, and chemokines) [8]. On the other hand, TNF- $\alpha$ activates TRADD and TRAF-2 [9] beside the "signalosome" complex recruiting IKK [10], transducing signals that activate NF- $\kappa$ B for tumor survival [11]. Survival cell tumor is the prelude of metastatic process and in this concern, the matrix metalloproteinase (MMP) 2 and 9 are involved in extracellular matrix degradation [12] [13] [14]. This leads to consequent neo-angiogenesis, vascular invasion and metastatic potential that characterize malignant tumors [15] [16] [17]. In many cancers, high levels of MMP-9 are associated with reversion-inducing cysteine rich protein with Kazal motifs (RECK) protein down-regulation [7] and recently Xu and coworkers [18], documented that in hepatoblastoma and neuroblastoma tissues, RECK inhibits the tumor invasion and metastasis through negative regulation of MMPs. In addition, it has been reported that Reactive Oxygen Species (ROS) may interfere with signal transduction pathways regulating the functions of NF- $\kappa \mathrm{B}$ [19] and are also able to decrease the HDAC2 activity [20]. Even if the effects of statins in cancer models have been investigated [21]-[28], to date no investigations documented the effects of statins in presence of HDAC2 downregulation. In this paper, we evaluated the effects of simvastatin on molecular pathways involved in inflammatory and metastatic pathway in non-small cell lung cancer line GLC-82, tranfected with shHDAC2 herein indicated as GLCshHDAC2 under oxidative stress condition.

\section{Materials and Methods}

\subsection{Cell Transfections}

The GLC-82 cells, grown to $70 \%$ of confluency on $60 \mathrm{~mm}$ tissue culture dishes (Falcon, Becton-Dickinson, Lincoln Park, NJ, USA), were transfected using the Calcium phosphate precipitation method employing a plasmid DNA mixture including $10 \mu \mathrm{g}$ of plasmid pCMV-delta R8.9, $2 \mu \mathrm{g}$ of plasmid p-VSV-G, $10 \mu \mathrm{g}$ of mission shRNA plasmid shHDAC2, (Sigma-Aldrich St. Louis USA). In the mixture, an equal volume of $2 x$ HBS (280 mm NaCl, $10 \mathrm{mM} \mathrm{KCl}, 1.5 \mathrm{~mm} \mathrm{Na} \mathrm{HPO}_{4}, 12 \mathrm{mM}$ dextrose, $50 \mathrm{mM}$ Hepes) $\mathrm{pH} 7.4$ 
was added. After $20 \mathrm{~min}$ at room temperature the solution was added dropwise to the GLC-82 plate. The plates were incubated at $37^{\circ} \mathrm{C}$ overnight. This was performed to generate GLCshHDAC2 cell line. The efficiency of transfection was estimated by fluorescence microscopy, controlling the transfection in a plate cloned with a p-GFP (Green Fluorescent Protein) control. At $24 \mathrm{~h}$ after transfection, the cells were maintained in a minimum volume of RPMI-3\% FBS in order to concentrate a viral titer.

\subsection{Lentiviral Transduction}

Supernatants harvested 48 and $72 \mathrm{~h}$ post-transfection were filtered $(0.45 \mu \mathrm{m}$ Whatman), and stored at $-80^{\circ} \mathrm{C}$ until use. GLC- 82 cells were plated on six-well plates (Falcon, Becton-Dickinson, Lincoln Park, NJ, USA) with $2 \times 10^{5}$ cell/well, $12 \mathrm{~h}$ before infection. Subsequently $2 \mathrm{ml}$ of lentivirus supernatant containing $6 \mu \mathrm{g} / \mathrm{ml}$ polybrene (Sigma St. Louis USA) were added to the cells and were submitted to "Spinoculation", centrifuged at $1800 \mathrm{rpm}$ for 40 minutes at a temperature of $32^{\circ} \mathrm{C}$, after $6 \mathrm{~h}$ of incubation cells were infected with a second inoculum of lentivirus supernatant at $37^{\circ} \mathrm{C}$ over night. The efficiency of the infection was estimated treating the cells with puromycin $(2$ $\mu \mathrm{g} / \mathrm{ml}$ ) (Bio-Australis Smithfield Australia), and by western blotting analysis using antibodies against the silenced proteins (see results). In another set of experiments, an empty lentivirus infection was used to evaluate the role of infection in the cell proliferation as well as in the pathway transduction. Data obtained from this experiment were evaluated respect to the data obtained using the control GLC-82 wild type not treated cells.

\subsection{Culture and Treatment of Human Lung Cancer Cells}

GLCshHDAC2 cell line, was cultured in RPMI 1640 MEDIUM (Sigma St. Louis U.S.A.) supplemented with $10 \%$ FBS, penicillin $100 \mathrm{U} / \mathrm{ml}$, streptomycin $100 \mu \mathrm{g} / \mathrm{ml}$, and fungizone $25 \mu \mathrm{g} / \mathrm{ml}$ (Sigma St. Louis U.S.A.). Lung cancer cells were maintained at $37^{\circ} \mathrm{C}$ in a humidified $5 \% \mathrm{CO}_{2}$ atmosphere then were split 1:2 at confluence, usually weekly, and finally they were plated in a 100-mm polystyrene dishes (Falcon, Becton-Dickinson, Lincoln Park, NJ, USA). In all experiments, we used cell lines at a passage earlier than the $10^{\text {th }}$. Simvastatin (40 mg) was dissolved in $2 \mathrm{~mL}$ of di-methyl-sulfoxide (DMSO, $100 \%$ ) and brought to a final volume of $10 \mathrm{~mL}$ in the free culture medium (stock solution, 0.1 M). This stock solution was diluted 1:10 (final solution, $0.01 \mathrm{M}$ ) and stored at $-20^{\circ} \mathrm{C}$. During our study, $30 \mu \mathrm{L}$ of the final solution $(30 \mu \mathrm{M})$ were added to each plate. When GLCshHDAC2 cells were a 50\% of confluence, they were exposed to hydrogen peroxide (0.5 mM) (Sigma St. Louis U.S.A) for $2 \mathrm{~h}$ and then treated with $30 \mu \mathrm{M}$ simvastatin for $24 \mathrm{~h}$. The medium was not changed after treatment. The solvent employed to dissolve these drugs was used as a control. After that period, the medium was removed for TNF- $\alpha$, IL-6 and IL-8 evaluation (see later) and cells were processed for protein extraction and immunoblotting.

\subsection{Cell Viability and Proliferation}

Cell viability was assessed by light microscopy using trypan blue; cell numbers were 
evaluated by direct counting, performed using a Burker chamber. Cell proliferation was investigated by Methylthiazolyldiphenyl-tetrazolium (MTT) bromide assay, based on the conversion by mitochondrial dehydrogenases of the substrate containing a tetrazolium ring into blue formazan, detectable spectrophotometrically. The level of blue formazan was used as an indirect index of cell density (Mosmann, 1983). Briefly, cells (100 $\mu \mathrm{l} /$ well) were seeded at a density of $1 \times 10^{4}$ cells $/ \mathrm{ml}$ into 96 well plates (Falcon, Becton-Dickinson, Lincoln Park, NJ, USA). Before and after treatment with $\mathrm{H}_{2} \mathrm{O}_{2}$ and Simvastatin, cell viability was assessed on a daily basis by adding $10 \mu \mathrm{l}$ of filter sterilised MTT (Sigma-aldrich Saint Louis U.S.A), $5 \mathrm{mg} / \mathrm{ml}$ in PBS, for 2 hours at $37^{\circ} \mathrm{C}$. The medium was then removed and cells were solubilized with acidified isopropanol (Sigmaaldrich Saint Louis U.S.A). After complete solubilization, presence of blue formazan was evaluated spectrophotometrically at a wavelength of 490 and $655 \mathrm{~nm}$. The optical density (O.D.) was calculated as the difference between the absorbance at the reference wavelength and that at the test wavelength. Percent viability was calculated as (O.D. of drug-treated sample/control O.D.) $\times 100$. All experiments were carried out in quadruplicate.

\subsection{Cell Cycle Determination}

After treatment with hydrogen peroxide $(0.5 \mathrm{mM})$ and simvastatin $(30 \mu \mathrm{M})$, cells were centrifuged at $1000 \mathrm{rpm}$ for $5 \mathrm{~min}$, the supernatant was withdrawn and the cell pellet washed two times with $2 \mathrm{~mL}$ of the PBS. Cells were fixed by incubation with $1 \mathrm{~mL}$ of $70 \%$ ethanol for $1 \mathrm{~h}$ at $-20^{\circ} \mathrm{C}$. After several washes the cells were then resuspended in 1 $\mathrm{mL}$ of staining solution (Propidium Iodide $500 \mu \mathrm{g} / \mathrm{ml}$, RNAsi $50 \mu \mathrm{g} / \mathrm{ml}, \mathrm{NP} 400.1 \%$ ) and incubated in the dark for $1 \mathrm{~h}$ at $37^{\circ} \mathrm{C}$. Subsequently the cells were washed three times with $2 \mathrm{~mL}$ of $1 \times$ PBS solution and analyzed through FACScan (Becton Dickinson, San Jose, CA) flow cytometer.

\subsection{Protein Extraction and Immunoblot Analysis}

Following treatment, cells were lysed for Western blotting in radioimmuno precipitation assay (RIPA) buffer, as previously described [29]. Nuclear extracts were obtained using the NE-PER cell fractionation kit (Thermo Scientific, Rockford, IL, USA). Briefly, whole cell lysates or nuclear proteins were then separated on a $12.5 \%$ sodium dodecyl sulfate-polyacrylamide gel electrophoresis (SDS-PAGE) and transferred onto polyvinylidene difluoride (PVDF) membranes (Amersham Pharmacia, Little Chalfont, UK). Immunoblotting was performed using the monoclonal antibodies listed below. Antibody binding was visualized by enhanced chemiluminescence (ECL-Plus; Amersham Pharmacia); intensities of experimental bands were analyzed by computer-assisted densitometry and expressed as arbitrary units, as previously described [30]. These experiments were performed in triplicate. All primary antibodies were used in a 1:1000 dilution in 5\% milk/TBS-T unless indicated otherwise. Primary antibody was incubated overnight at $4^{\circ} \mathrm{C}$ on a rotating wheel. The primary antibodies used were: Anti-p-Erk, Anti-NFkB p65, Anti-TRADD, Anti-MyD88, Anti-TRAF6, Anti-TRAF2, Anti-RECK, 
Anti-MMP-9, Anti-MMP-2, Anti-HDAC2, Anti-Y-Tubulin, Anti-Actin (Santacruz, USA). All secondary antibodies were used in a 1:2000 dilution in 5\% milk/TBS-T and incubated with the blot for $2 \mathrm{~h}$ at room temperature. The secondary antibodies used were: Goat anti-mouse IgG-HRP conjugated, Goat anti-rabbit IgG-HRP conjugated, Donkey anti-goat IgG-HRP conjugated (Santacruz, USA).

\subsection{Enzyme-Linked Immunoabsorbent Assay (ELISA) Assay}

The amount of TNF- $\alpha$, IL- 6 and IL- 8 released in the supernatant of treated cells was determined by an ELISA assay (Quantikine, R \& D system) according to the manufacturer instructions.

\subsection{Statistical Analysis}

All data are expressed as mean \pm SEM. Statistical evaluation of the results was performed by Anova. Differences identified by Anova were pointed by unpaired Student's $t$-test. The threshold of statistical significance was set at $\mathrm{P}<0.05$.

\section{Results}

\subsection{Determining the GLCshHDAC2 Cells Line}

Figure 1(a) lane 1 shows the expression of HDA2 in GLC-82 cells (wild type) by western blotting analysis. In Figure 1(a) lane 2 after infection with lentivirus containing the shHDAC2, is highlighted a decreasing in HDCA2 level. The densitometric analysis of the targets in A (Figure 1(b)) demonstrates that almost the 70\% of HDA2 result decreased.

\subsection{Proliferation of GLCshHDAC2 Cells Line}

MTT assay in GLCshHDAC2 cells, show that $\mathrm{H}_{2} \mathrm{O}_{2}$ pretreatment induced proliferation

GLCWT

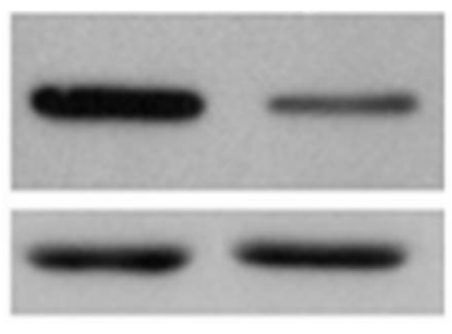

(a)

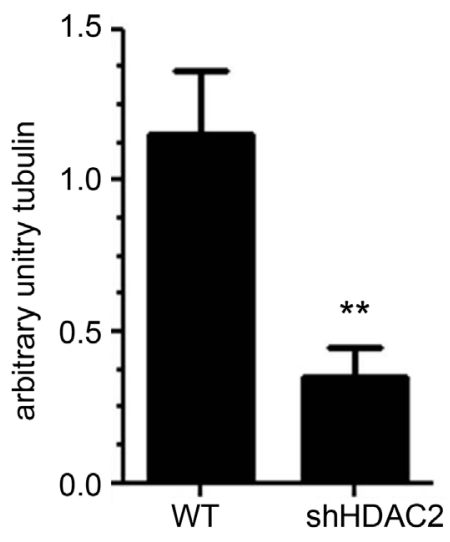

(b)

Figure 1. Inhibition of histone deacetylase proteins. (a) Expression of HDAC2 protein in GLC wild-type and in cells infected with a lentiviral vector containing a shRNA against histone deacetylase of type 2 evaluated through western blotting in GLC cells. (b) Densitometry analysis of targets in A. 
(of about $30 \%$ more) of those cells respect to the control without $\mathrm{H}_{2} \mathrm{O}_{2}$ pretreatment (Figure 2(a)). Further 24 hours simvastatin treatment significantly decreased $(\mathrm{P}<0.01)$ the cells count prominently in respect to $\mathrm{H}_{2} \mathrm{O}_{2}$ pretreatment (Figure 2(b)).

\subsection{Cell Cycle Comparison between GLC-82 and GLCshHDAC2}

As shown in Table 1, in GLCshHDAC2 cells G0/G1 phase increase, while decrease S and G2/M-phases respect to GLC-82 wild type. In both cells line simvastatin $(30 \mu \mathrm{M})$ induced a significant increase in G0/G1 phase, and a decrease in S and G2/M-phase respect to control cells $(\mathrm{P}<0.01)$. In contrast, $\mathrm{H}_{2} \mathrm{O}_{2}(0.5 \mathrm{mM})$ induced a significant decrease of G0/G1 and a significant increase in $S$ and $G 2 / M$ phase $(P<0.01)$ compared to controls; these effects were significantly reverted by simvastatin treatment $(\mathrm{P}<0.01)$.

\subsection{Activation of Biochemical Signaling Pathway in GLCshHDAC2}

As shown in Figure 3 in the GLCshHDAC2 cell line, the pretreatment with $\mathrm{H}_{2} \mathrm{O}_{2}$ followed by simvastatin action induced a significant increase in a) ERK1/2 phosphorylation

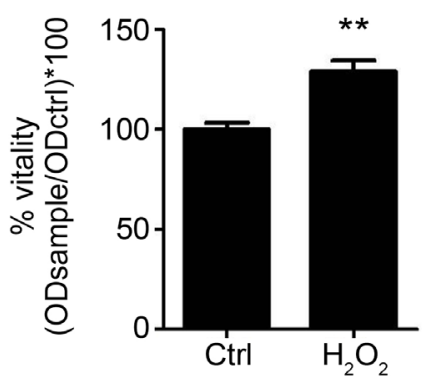

(a)

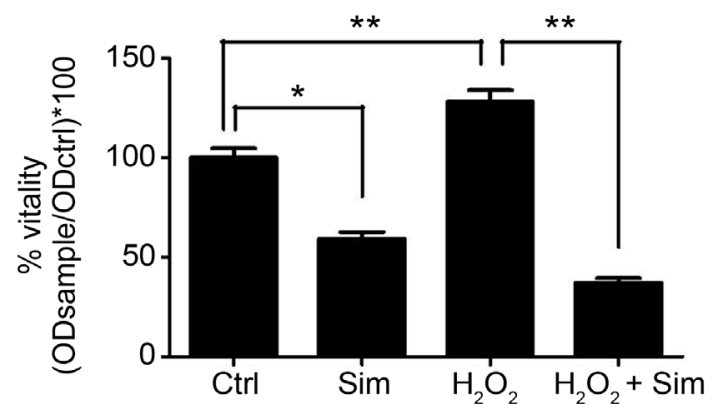

(b)

Figure 2. Simvastatin modify both cell growth and the effect of $\mathrm{H}_{2} \mathrm{O}_{2}$ on cell proliferation. Effects of hydrogen peroxide $\left(\mathrm{H}_{2} \mathrm{O}_{2}\right)$ in presence or absence of a 24 hours of simvastatin treatment (30 $\mu \mathrm{M})$ on GLC-82/shHDAC2 inhibited cell counts, expressed as absorbance. ${ }^{*} \mathrm{P}<0.01$ simvastatin vs control; \# $\mathrm{P}<0.01 \mathrm{H}_{2} \mathrm{O}_{2}+$ simvastatin vs. $\mathrm{H}_{2} \mathrm{O}_{2}$.

Table 1. Cell cycle phases evaluation in presence or in absence of $\mathrm{H}_{2} \mathrm{O}_{2}$ or $\mathrm{H}_{2} \mathrm{O}_{2}+$ Simvastatin.

\begin{tabular}{cccc}
\hline Cellular cycle phases & \%G0/G1 & $\% \mathrm{~S}$ & $\% \mathrm{G} 2 / \mathrm{M}$ \\
\hline & GLC-82 wild type & & \\
\hline Control & $35.8 \pm 0.8$ & $32.2 \pm 0.7$ & $32.0 \pm 0.5$ \\
Simvastatin $(30 \mu \mathrm{M})$ & $61.4 \pm 0.5$ & $22.2 \pm 0.6$ & $16.4 \pm 0.4$ \\
$\mathrm{H}_{2} \mathrm{O}_{2}(0.5 \mathrm{mM})$ & $21.0 \pm 0.6$ & $39.7 \pm 0.3$ & $39.3 \pm 0.7$ \\
$\mathrm{H}_{2} \mathrm{O}_{2}(0.5 \mathrm{mM})+\operatorname{simvastatin}(30 \mu \mathrm{M})$ & $55.2 \pm 0.3$ & $28.3 \pm 0.2$ & $16.5 \pm 0.3$ \\
\hline & GLCshHDAC2 & & \\
\hline Control & $58.1 \pm 1.1$ & $27.3 \pm 0.7$ & $14.6 \pm 0.4$ \\
Simvastatin $(30 \mu \mathrm{M})$ & $76.0 \pm 0.2$ & $11.6 \pm 0.8$ & $12.4 \pm 0.4$ \\
$\mathrm{H}_{2} \mathrm{O}_{2}(0.5 \mathrm{mM})$ & $28.4 \pm 0.4$ & $39.5 \pm 0.3$ & $32.1 \pm 0.3$ \\
$\mathrm{H}_{2} \mathrm{O}_{2}(0.5 \mathrm{mM})+\operatorname{simvastatin}(30 \mu \mathrm{M})$ & $65.2 \pm 0.8$ & $17.6 \pm 0.5$ & $17.2 \pm 0.7$ \\
\hline
\end{tabular}




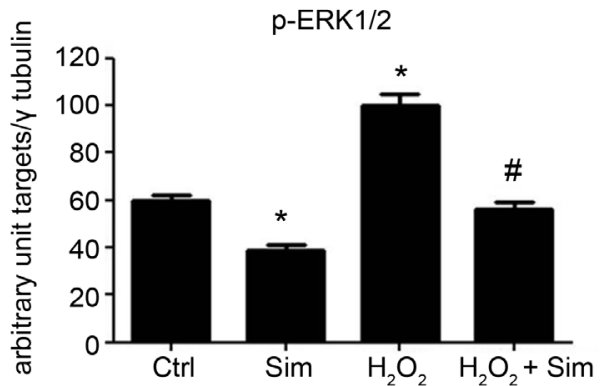

(a)

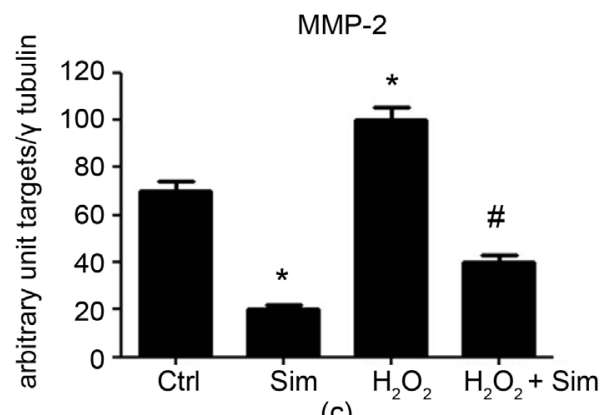

(c)

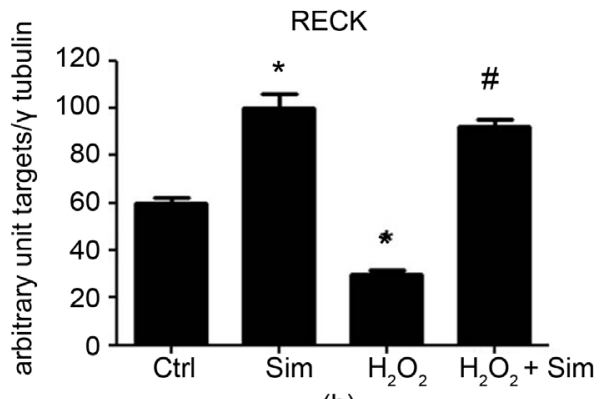

(b)

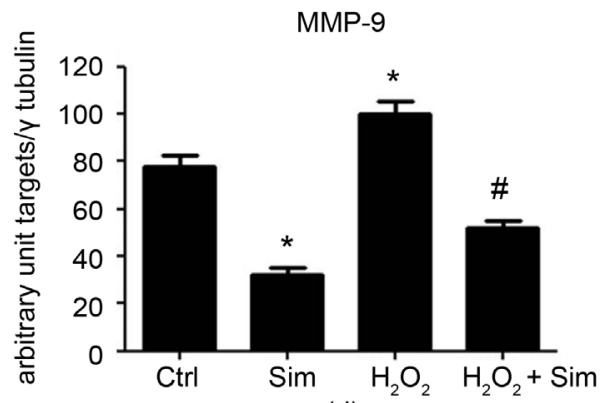

(d)

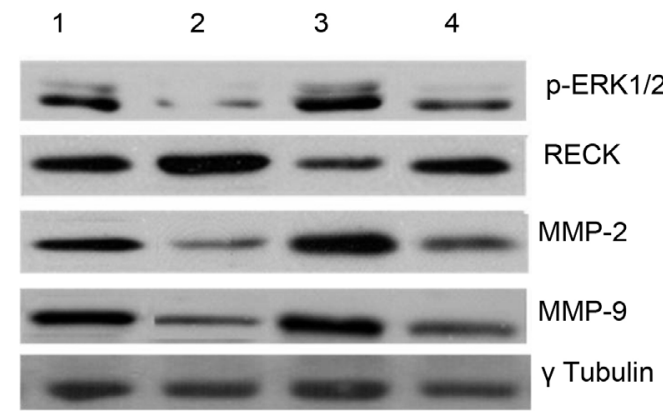

Figure 3. Activation of biochemical signaling pathway in GLCshHDAC2. Densitometry graph of western blot evaluation in GLCshHDAC2 cells of (a) phosphorylated ERK 1/2 (p-ERKs) expression following or not $\mathrm{H}_{2} \mathrm{O}_{2}$ pretreatment (lane 1 and 3), and in the presence or absence of simvastatin for 24 hours (lane 2 and 4). In (b) RECK (c) MMP-2 and (d) MMP-9 expression in the same condition described above. Data represent the mean \pm SEM of three experiments. ${ }^{\star} \mathrm{P}<0.01$ vs control; $\# \mathrm{P}<0.01$ vs. $\mathrm{H}_{2} \mathrm{O}$.

pretreatment. Followed by a significant decrease of $b)$ RECK expression $(\mathrm{P}<0.01)$ a significant increase $(\mathrm{P}<0.01)$ of both $\mathrm{c}) \mathrm{MMP}-2$ and $\mathrm{d}$ ) MMP-9 expression (Figure $3(\mathrm{c})$ and Figure $3(\mathrm{~d})$ ). Data represent the mean \pm SEM of three independent experiments (lane 2 and 4). ${ }^{*} \mathrm{P}<0.01$ vs. control; $\# \mathrm{P}<0.01$ vs. $\mathrm{H}_{2} \mathrm{O}_{2}$ (lane 1 and 3). In Figure 4 , under the same condition decribed above, it show an increase of a) NF- $\kappa \mathrm{B}$ expression, b) MyD88, c) TRAF-6, d) TRADD and e) TRAF-2 (lane 2 and 4). All of these effects were significantly $(\mathrm{P}<0.01)$ reverted by simvastatin $(30 \mu \mathrm{M})$ treatment.

\subsection{TNF- $\alpha$, IL-6 and IL-8 Secretion by GLCshHDAC2 Cell Line}

ELISA assay in GLCshHDAC2 cells under $\mathrm{H}_{2} \mathrm{O}_{2}(0.5 \mathrm{mM})$ show a significantly increase $(\mathrm{P}<0.01)$ of TNF- $\alpha$, IL- 6 and IL-8 secretion in cell surnatant media, these effects were 


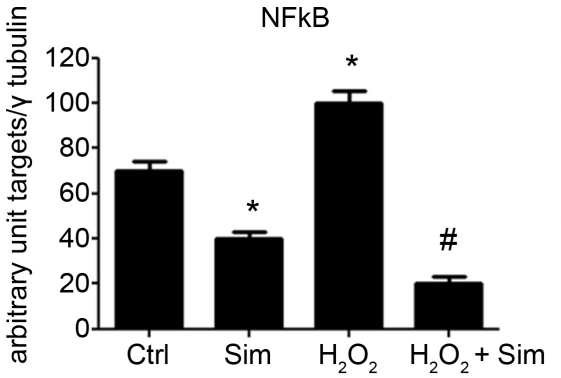

(a)

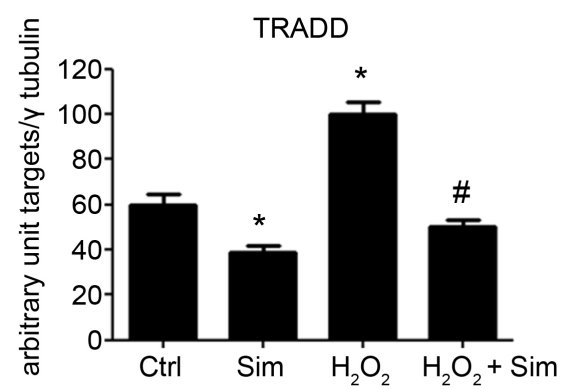

(c)

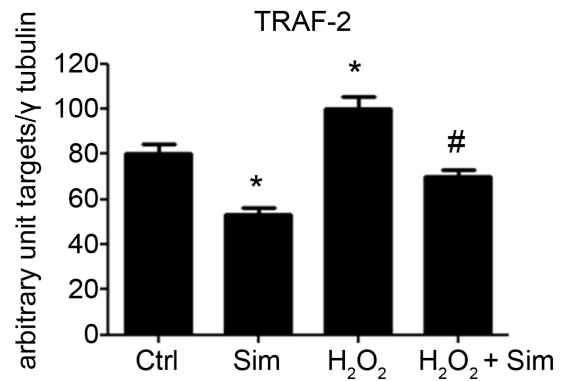

(e)

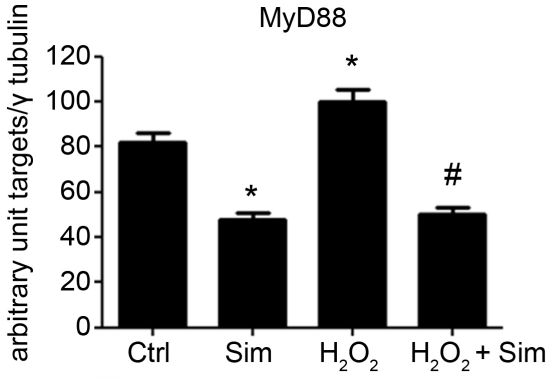

(b)

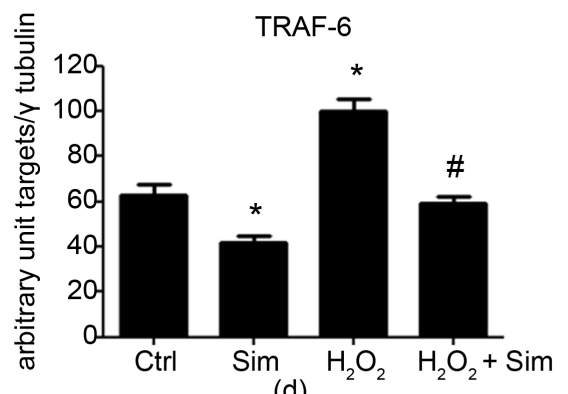

(d)

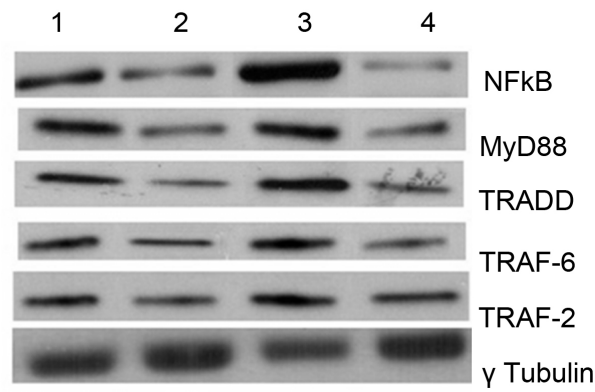

Figure 4. Activation of biochemical signaling pathway in GLCshHDAC2. Densitometry graph of western blot evaluation in GLCshHDAC2 cells of (a) Nuclear factor- $\kappa$ B (NF- $\kappa$ B) expression following or not $\mathrm{H}_{2} \mathrm{O}_{2}$ pretreatment (lane 1 and 3), and in the presence or absence of simvastatin for 24 hours (lane 2 and 4). In (b) MyD88, (c) TRADD, TRAF-2 and 6 in (d) and (e) expression in the same condition described above. Data represent the mean \pm SEM of three experiments. ${ }^{\star} \mathrm{P}<$ 0.01 vs. control; $\# \mathrm{P}<0.01$ vs. $\mathrm{H}_{2} \mathrm{O}_{2}$.

significantly countered $(\mathrm{P}<0.01)$ by a $24 \mathrm{~h}$ treatment with simvastatin $(30 \mu \mathrm{M})$ (Figures 5(a)-(c)).

\section{Discussion}

The first important finding of our study is that the effect of simvastatin overcomes histone deacetylase type 2 enzymes (HDAC2) expression in non-small cell lung cancer established by lentivirus transfection and herein indicated as GLCshHDAC2. Up today the mechanism of action of statins, including simvastatin, on cancer pathways was ascribed to the inhibition of this class of enzymes. HDACs play a role in both inflammation [31] [32] and metastasis [33]. The HDAC2 isoform has been documented overexpressed in oral tumors suggesting a correlation with poor prognosis [34]. Bolden et al. 


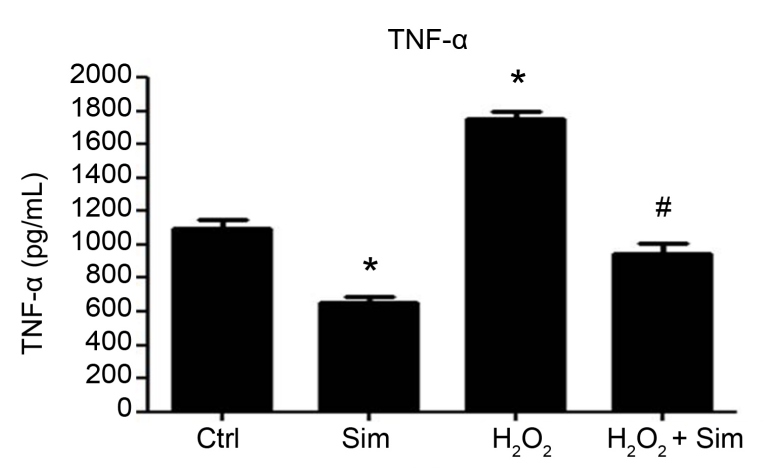

(a)

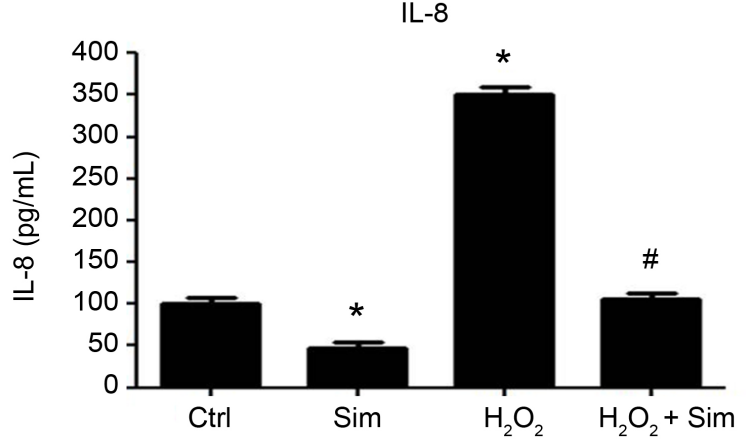

(b)

IL-6

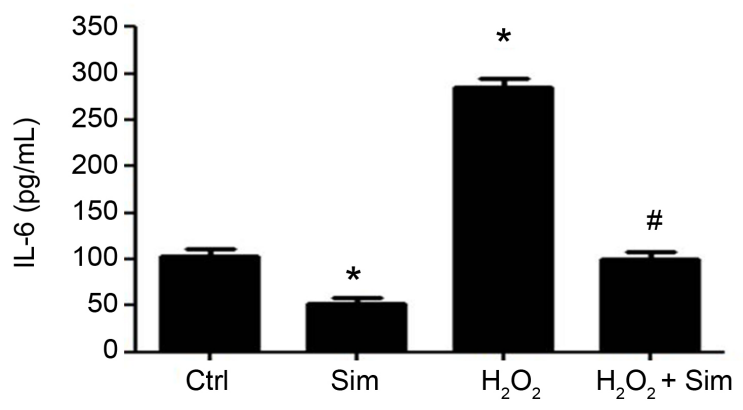

(c)

Figure 5. TNF- $\alpha$ IL-6 and IL-8 secretion by GLCshHDAC2 cell line. ELISA assay in GLCshHDAC2 cells of (a) Tumor Necrosis Factor- $\alpha$ (TNF- $\alpha$ ) secretion following or not $\mathrm{H}_{2} \mathrm{O}_{2}$ pretreatment, and in the presence or absence of simvastatin for 24 hours. In (b) IL-8, (c) IL-6. Data represent the mean \pm SEM of three experiments. ${ }^{\star} \mathrm{P}<0.01$ vs. control; \#P $<$ 0.01 vs. $\mathrm{H}_{2} \mathrm{O}_{2}$.

on the basis of a detailed literature review, highlighted that HDAC inhibitors can induce anticancer effects, tumor cell apoptosis, cell cycle arrest, differentiation, senescence, modulation of immune responses, and altered angiogenesis [35]. Previously it has been reported that statins are potent inhibitor of HDACs [36] supporting their role in cancer treatment [37]. In agreement, it has been demonstrated that statins may have a cytostatic effect on cancer cells, and can extend cancer patients survival [38]. Cardwell and coworkers [39], evaluating 3638 lung cancer patients, documented that simvastatin 
use was associated with reduced lung cancer mortality. These effects seem to be related with anti-oxidant, anti-inflammatory and anti-angiogenic effects of statins [40] and could explain the statin's effects on several pathways related to lung cancer [21] [22] [23]. Conversely, studying five head and neck cancer cell lines, it was shown that silencing HDAC2 expression resulted in initiation of tumors growth, suggesting a role of HDAC2 in cancer development [41]. In this light, we evaluated the effects of simvastatin on GLCshHDAC2 cells here. HDAC2 expression is strongly reduced by lentiviral transfection (Figure 1(a) and Figure 1(b)). We exposed this cell line to hydrogen peroxide $\left(\mathrm{H}_{2} \mathrm{O}_{2}\right)$ and we focused our attention on several biochemical pathways triggered by oxidative stress. We documented that in GLCshHDAC2, the cell viability evaluated by MTT assay, was significant impaired respect to the control group. Moreover, the cell line GLCshHDAC2 was more sensitive to decreasing cell viability under simvastatin treatment in presence of oxidative stress induction by $\mathrm{H}_{2} \mathrm{O}_{2}$. To evaluate whether down regulated HDAC2 expression may modulate the cell cycle progression, we used flow cytometry analysis, in order to see changes in cell cycle distribution before and after HDAC2 shRNA transfection. We documented cell cycle arrest in G0/G1 phase and a decrease of S-phase in GLCshHDAC2. The pretreatment with $\mathrm{H}_{2} \mathrm{O}_{2}$, caused an increase in cell proliferation in both GLC-82 wild type and GLCshHDAC2 cells, respect to the control levels. These effects were significantly reduced by simvastatin, particularly in GLCshHDAC2 cells, suggesting a mechanism of action of simvastatin that goes beyond the only inhibitory HDACs activity. Taken together, these results suggest that HDAC2 down-regulation, as well as simvastatin treatment modulates the cell cycle in both wild type and in GLCshHDAC2 cell lines.

Liu et al. showed that in CL-1 human lung cells [42], the HDAC inhibitor trichostatin1 stimulates RECK expression and concomitantly reduces MMP-2 activity and consequently cancer cell invasion. Consistently with these results, in ovarian carcinoma cells, Chen et al. [43] found that the HDAC inhibitor suberoylanilide hydroxamic acid, decreases the phosphorylation of ERK1/2 and the expression MMP-9, respectively involved in cell proliferation and metastasis. Here we report that the pharmacological action of simvastatin is explicated on the diminishing of the post-translation modification of ERK1/2. Less phosphorylation of the ERK1/2 denotes a delay in proliferation even in presence of oxidative stress, confirmed by cell cycle investigation through flow cytometry analysis. In this concern, simvastation in cell line, GLC-82 wild type and GLCshHDAC2 induced a significant decrease in S phase. Further, simvastatin in GLCshHDAC2, increased the expression of RECK, while decreased the expression of both MMP-2 and MMP-9.

The above-mentioned biochemical signaling pathways converge towards NF- $\kappa \mathrm{B}$ activation that in turns, is able to induce also an increased secretion of proinflammatory cytokines [21] [22]. The recruitment of MyD88 is able to activate NF- $\kappa$ B. Here MyD88 is downregulated under simvastatin treatment. Since, NF- $\kappa \mathrm{B}$ regulates the transcription of genes related to proteins synthesis, including pro-inflammatory cytokines such as IL-8, IL-6, TNF-alpha, IL-12 and macrophage inflammatory protein (MIP-1/2) [21] 
[22] [44], we analyzed NF- $\kappa$ B expression resulted, as expected decreased and the cytokines secretion. In particular $\mathrm{TNF} \alpha$, able to activate TRADD and TRAF-2 (Srivastava, Qin et al. 2007) resulted diminished. Moreover, simvastain was able to downregulate TRADD expression and both TRAF-2 and 6 in absence or not of oxidative stress stimuli and the level of IL-8 and 6. Yang et al. [5], reported that NF- $\kappa$ B-mediates lung inflammation, associated with modifications of HDAC2 expression induced by the oxidative stress stimulus of cigarette smoke. Therefore, HDAC2 expression and activity impairment trigger inflammatory pathways and reduce the therapeutic responses to corticosteroids [45]. In contrast in the present paper, the effects recorded in GLCshHDAC2 cells after $\mathrm{H}_{2} \mathrm{O}_{2}$ exposition, were reverted by simvastatin treatment suggesting that its effect overcame HDAC2 expression.

\section{Conflicts of Interest}

The authors disclose no potential conflicts of interest.

\section{References}

[1] Soneji, S. and Yang, J. (2015) New Analysis Reexamines the Value of Cancer Care in the United States Compared to Western Europe. Health Affairs (Millwood), 34, 390-397. http://dx.doi.org/10.1377/hlthaff.2014.0174

[2] Tsai, M.F., Wang, C.C. and Chen, J.J. (2014) Tumour Suppressor HLJ1: A Potential Diagnostic, Preventive and Therapeutic Target in Non-Small Cell Lung Cancer. World Journal of Clinical Oncology, 5, 865-873. http://dx.doi.org/10.5306/wjco.v5.i5.865

[3] D’Agostino, B., Marrocco, G., De Nardo, M., Calò, G., Guerrini, R., Gallelli, L., Advenier, C. and Rossi, F. (2005) Activation of the Nociceptin/Orphanin FQ Receptor Reduces Bronchoconstriction and Microvascular Leakage in a Rabbit Model of Gastroesophageal Reflux. British Journal of Pharmacology, 144, 813-820. http://dx.doi.org/10.1038/sj.bjp.0706066

[4] D’Agostino, B., Orlotti, D., Calò, G., Sullo, N., Russo, M., Guerrini, R., De Nardo, M., Mazzeo, F., Candeletti, S. and Rossi, F. (2010) Nociceptin Modulates Bronchoconstriction Induced by Sensory Nerve Activation in Mouse Lung. American Journal of Respiratory Cell and Molecular Biology, 42, 250-254. http://dx.doi.org/10.1165/rcmb.2008-0488OC

[5] Yang, S.R., Chida, A.S., Bauter, M.R., Shafiq, N., Seweryniak, K., Maggirwar, S.B., Kilty, I. and Rahman, I. (2006) Cigarette Smoke Induces Proinflammatory Cytokine Release by Activation of NF-KappaB and Posttranslational Modifications of Histone Deacetylase in Macrophages. American Journal of Physiology, Lung Cellular and Molecular Physiology, 291, L46-L57. http://dx.doi.org/10.1152/ajplung.00241.2005

[6] Deryugina, E.I. and Quigley, J.P. (2006) Matrix Metalloproteinases and Tumor Metastasis. Cancer Metastasis Reviews, 25, 9-34. http://dx.doi.org/10.1007/s10555-006-7886-9

[7] Takahashi, C., Sheng, Z., Horan, T.P., Kitayama, H., Maki, M., Hitomi, K., Kitaura, Y., Takai, S., Sasahara, R.M., Horimoto, A., Ikawa, Y., Ratzkin, B.J., Arakawa, T. and Noda, M. (1998) Regulation of Matrix Metalloproteinase-9 and Inhibition of Tumor Invasion by the Membrane-Anchored Glycoprotein RECK. Proceedings of the National Academy of Sciences of the United States of America, 95, 13221-13226. http://dx.doi.org/10.1073/pnas.95.22.13221

[8] Ahn, K.S. and Aggarwal, B.B. (2005) Transcription Factor NF-KappaB: A Sensor for Smoke and Stress Signals. Annals of the New York Academy of Sciences, 1056, 218-233. 
http://dx.doi.org/10.1196/annals.1352.026

[9] Srivastava, A.K., Qin, X., Wedhas, N., Arnush, M., Linkhart, T.A., Chadwick, R.B. and Kumar, A. (2007) Tumor Necrosis Factor-Alpha Augments Matrix Metalloproteinase-9 Production in Skeletal Muscle Cells through the Activation of Transforming Growth FactorBeta-Activated Kinase 1 (TAK1)-Dependent Signaling Pathway. The Journal of Biological Chemistry, 282, 35113-35124. http://dx.doi.org/10.1074/jbc.M705329200

[10] Wallach, D., Varfolomeev, E.E., Malinin, N.L., Goltsev, Y.V., Kovalenko, A.V. and Boldin, M.P. (1999) Tumor Necrosis Factor Receptor and Fas Signaling Mechanisms. Annual Review of Immunology, 17, 331-367. http://dx.doi.org/10.1146/annurev.immunol.17.1.331

[11] Micheau, O. and Tschopp, J. (2003) Induction of TNF Receptor I-Mediated Apoptosis via Two Sequential Signaling Complexes. Cell, 114, 181-190.

http://dx.doi.org/10.1016/S0092-8674(03)00521-X

[12] Serra, R., Buffone, G., Falcone, D., Molinari, V., Scaramuzzino, M., Gallelli, L. and de Franciscis, S. (2013) Chronic Venous Leg Ulcers Are Associated with High Levels of Metalloproteinases-9 and Neutrophil Gelatinase-Associated Lipocalin. Wound Repair and Regeneration, 21, 395-401.

[13] Serra, R., Grande, R., Montemurro, R., Butrico, L., Calio, F.G., Mastrangelo, D., Scarcello, E., Gallelli, L., Buffone, G. and de Franciscis, S. (2015) The Role of Matrix Metalloproteinases and Neutrophil Gelatinase-Associated Lipocalin in Central and Peripheral Arterial Aneurysms. Surgery, 157, 155-162. http://dx.doi.org/10.1016/j.surg.2014.06.008

[14] Serra, R., Grande, R., Buffone, G., Gallelli, L. and de Franciscis, S. (2013) The Effects of Minocycline on Extracellular Matrix in Patients with Chronic Venous Leg Ulcers. Acta Phlebologica, 14, 99-107.

[15] Egeblad, M. and Werb, Z. (2002) New Functions for the Matrix Metalloproteinases in Cancer Progression, Nature Reviews. Cancer, 2, 161-174. http://dx.doi.org/10.1038/nrc745

[16] Duffy, M.J., Maguire, T.M., Hill, A., McDermott, E. and O'Higgins, N. (2000) Metalloproteinases: Role in Breast Carcinogenesis, Invasion and Metastasis. Breast Cancer Research, 2, 252-257. http://dx.doi.org/10.1186/bcr65

[17] Curran, S. and Murray, G.I. (2000) Matrix Metalloproteinases: Molecular Aspects of Their Roles in Tumour Invasion and Metastasis. European Journal of Cancer, 36, 1621-1630. http://dx.doi.org/10.1016/S0959-8049(00)00156-8

[18] Xu, M., Wang, H.F. and Zhang, H.Z. (2015) Expression of RECK and MMPs in Hepatoblastoma and Neuroblastoma and Comparative Analysis on the Tumor Metastasis. Asian Pacific Journal of Cancer Prevention, 16, 4007-4011. http://dx.doi.org/10.7314/APJCP.2015.16.9.4007

[19] Chung, K.F. and Adcock, I.M. (2008) Multifaceted Mechanisms in COPD: Inflammation, Immunity, and Tissue Repair and Destruction. The European Respiratory Journal, 31, 1334-1356. http://dx.doi.org/10.1183/09031936.00018908

[20] Sundar, I.K., Yao, H. and Rahman, I. (2013) Oxidative Stress and Chromatin Remodeling in Chronic Obstructive Pulmonary Disease and Smoking-Related Diseases. Antioxidants \& Redox Signaling, 18, 1956-1971. http://dx.doi.org/10.1089/ars.2012.4863

[21] Gallelli, L., Falcone, D., Scaramuzzino, M., Pelaia, G., D’Agostino, B., Mesuraca, M., Terracciano, R., Spaziano, G., Maselli, R., Navarra, M. and Savino, R. (2014) Effects of Simvastatin on Cell Viability and Proinflammatory Pathways in Lung Adenocarcinoma Cells Exposed to Hydrogen Peroxide. BMC Pharmacology \& Toxicology, 15, 67. http://dx.doi.org/10.1186/2050-6511-15-67

[22] Falcone, D., Gallelli, L., Di Virgilio, A., Tucci, L., Scaramuzzino, M., Terracciano, R., Pelaia, 
G. and Savino, R. (2013) Effects of Simvastatin and Rosuvastatin on RAS Protein, Matrix Metalloproteinases and NF-KappaB in Lung Cancer and in Normal Pulmonary Tissues. Cell Proliferation, 46, 172-182. http://dx.doi.org/10.1111/cpr.12018

[23] Pelaia, G., Gallelli, L., Renda, T., Fratto, D., Falcone, D., Caraglia, M., Busceti, M.T., Terracciano, R., Vatrella, A., Maselli, R. and Savino, R. (2012) Effects of Statins and Farnesyl Transferase Inhibitors on ERK Phosphorylation, Apoptosis and cell Viability in Non-Small Lung Cancer Cells. Cell Proliferation, 45, 557-565. http://dx.doi.org/10.1111/j.1365-2184.2012.00846.x

[24] Park, Y.H., Jung, H.H., Ahn, J.S. and Im, Y.H. (2013) Statin Induces Inhibition of Triple Negative Breast Cancer (TNBC) Cells via PI3K Pathway. Biochemical and Biophysical Research Communications, 439, 275-279. http://dx.doi.org/10.1016/j.bbrc.2013.08.043

[25] Hoque, A., Chen, H. and Xu, X.C. (2008) Statin Induces Apoptosis and Cell Growth Arrest in Prostate Cancer Cells. Cancer Epidemiology Biomarkers \& Prevention, 17, 88-94. http://dx.doi.org/10.1158/1055-9965.EPI-07-0531

[26] Feldt, M., Bjarnadottir, O., Kimbung, S., Jirstrom, K., Bendahl, P.O., Veerla, S., Grabau, D., Hedenfalk, I. and Borgquist, S. (2015) Statin-Induced Anti-Proliferative Effects via Cyclin D1 and p27 in a Window-of-Opportunity Breast Cancer Trial. Journal of Translational Medicine, 13, 133. http://dx.doi.org/10.1186/s12967-015-0486-0

[27] Mandal, C.C. and Rahman, M.M. (2014) Targeting Intracellular Cholesterol Is a Novel Therapeutic Strategy for Cancer Treatment. Journal of Cancer Science \& Therapy, 6, 510513. http://dx.doi.org/10.4172/1948-5956.1000316

[28] Shen, Y.Y., Yuan, Y., Du, Y.Y. and Pan, Y.Y. (2015) Molecular Mechanism Underlying the Anticancer Effect of Simvastatin on MDA-MB-231 Human Breast Cancer Cells. Molecular Medicine Reports, 12, 623-630. http://dx.doi.org/10.3892/mmr.2015.3411

[29] Gallelli, L., Pelaia, G., Fratto, D., Muto, V., Falcone, D., Vatrella, A., Curto, L.S., Renda, T., Busceti, M.T., Liberto, M.C., Savino, R., Cazzola, M., Marsico, S.A. and Maselli, R. (2010) Effects of Budesonide on P38 MAPK Activation, Apoptosis and IL-8 Secretion, Induced by TNF-Alpha and Haemophilus influenzae in Human Bronchial Epithelial Cells. International Journal of Immunopathology and Pharmacology, 23, 471-479.

[30] Gallelli, L., Falcone, D., Pelaia, G., Renda, T., Terracciano, R., Malara, N., Vatrella, A., Sanduzzi, A., D’Agostino, B., Rossi, F., Vancheri, C., Maselli, R., Marsico, S.A. and Savino, R. (2008) Interleukin-6 Receptor Superantagonist Sant7 Inhibits TGF-Beta-Induced Proliferation of Human Lung Fibroblasts. Cell Proliferation, 41, 393-407.

http://dx.doi.org/10.1111/j.1365-2184.2008.00538.x

[31] Gallelli, L., D’Agostino, B., Marrocco, G., De Rosa, G., Filippelli, W., Rossi, F. and Advenier, C. (2003) Role of Tachykinins in the Bronchoconstriction Induced by HCl Intraesophageal Instillation in the Rabbit. Life Sciences, 72, 1135-1142.

http://dx.doi.org/10.1016/S0024-3205(02)02372-X

[32] D’Agostino, B., Advenier, C., de Palma, R., Gallelli, L., Marrocco, G., Abbate, G.F. and Rossi, F. (2002) The Involvement of Sensory Neuropeptides in Airway Hyper-Responsiveness in Rabbits Sensitized and Challenged to Parietaria judaica. Clinical and Experimental Allergy, 32, 472-479. http://dx.doi.org/10.1046/j.1365-2222.2002.01328.x

[33] Villagra, A., Sotomayor, E.M. and Seto, E. (2010) Histone Deacetylases and the Immunological Network: Implications in Cancer and Inflammation. Oncogene, 29, 157-173. http://dx.doi.org/10.1038/onc.2009.334

[34] Chang, H.H., Chiang, C.P., Hung, H.C., Lin, C.Y., Deng, Y.T. and Kuo, M.Y. (2009) Histone Deacetylase 2 Expression Predicts Poorer Prognosis in Oral Cancer Patients. Oral Oncology, 45, 610-614. http://dx.doi.org/10.1016/j.oraloncology.2008.08.011 
[35] Bolden, J.E., Peart, M.J. and Johnstone, R.W. (2006) Anticancer Activities of Histone Deacetylase Inhibitors. Nature Reviews Drug Discovery, 5, 769-784.

http://dx.doi.org/10.1038/nrd2133

[36] Chen, J.B., Chern, T.R., Wei, T.T., Chen, C.C., Lin, J.H. and Fang, J.M. (2013) Design and Synthesis of Dual-Action Inhibitors Targeting Histone Deacetylases and 3-Hydroxy-3Methylglutaryl Coenzyme A Reductase for Cancer Treatment. Journal of Medicinal Chemistry, 56, 3645-3655. http://dx.doi.org/10.1021/jm400179b

[37] Gao, Y., Lu, X.C., Yang, H.Y., Liu, X.F., Cao, J. and Fan, L. (2012) The Molecular Mechanism of the Anticancer Effect of Atorvastatin: DNA Microarray and Bioinformatic Analyses. International Journal of Molecular Medicine, 30, 765-774.

[38] Nielsen, S.F., Nordestgaard, B.G. and Bojesen, S.E. (2012) Statin Use and Reduced CancerRelated Mortality. The New England Journal of Medicine, 367, 1792-1802. http://dx.doi.org/10.1056/NEJMoa1201735

[39] Cardwell, C.R., Menamin, U., Hughes, C.M. and Murray, L.J. (2015) Statin Use and Survival from Lung Cancer: A Population-Based Cohort Study. Cancer Epidemiology Biomarkers \& Prevention, 24, 833-841. http://dx.doi.org/10.1158/1055-9965.EPI-15-0052

[40] Beri, A., Sural, N. and Mahajan, S.B. (2009) Non-Atheroprotective Effects of Statins: A Systematic Review. American Journal of Cardiovascular Drugs, 9, 361-370. http://dx.doi.org/10.2165/11315710-000000000-00000

[41] Chang, C.C., Lin, B.R., Chen, S.T., Hsieh, T.H., Li, Y.J. and Kuo, M.Y. (2011) HDAC2 Promotes Cell Migration/Invasion Abilities through HIF-1Alpha Stabilization in Human Oral Squamous Cell Carcinoma. Journal of Oral Pathology \& Medicine, 40, 567-575. http://dx.doi.org/10.1111/j.1600-0714.2011.01009.x

[42] Liu, L.T., Chang, H.C., Chiang, L.C. and Hung, W.C. (2003) Histone Deacetylase Inhibitor up-Regulates RECK to Inhibit MMP-2 Activation and Cancer Cell Invasion. Cancer Research, 63, 3069-3072.

[43] Chen, S., Zhao, Y., Gou, W.F., Zhao, S., Takano, Y. and Zheng, H.C. (2013) The Anti-Tumor Effects and Molecular Mechanisms of Suberoylanilide Hydroxamic Acid (SAHA) on the Aggressive Phenotypes of Ovarian Carcinoma Cells. PLOS ONE, 8, e79781. http://dx.doi.org/10.1371/journal.pone.0079781

[44] Yang, B.C., Yang, Z.H., Pan, X.J., Xiao, F.J., Liu, X.Y., Zhu, M.X. and Xie, J.P. (2013) Crotonaldehyde-Exposed Macrophages Induce IL-8 Release from Airway Epithelial Cells through NF-Kappa B and AP-1 Pathways. Toxicology Letters, 219, 26-34. http://dx.doi.org/10.1016/j.toxlet.2013.02.018

[45] Charron, C.E., Chou, P.C., Coutts, D.J., Kumar, V., To, M., Akashi, K., Pinhu, L., Griffiths, M., Adcock, I.M., Barnes, P.J. and Ito, K. (2009) Hypoxia-Inducible Factor 1Alpha Induces Corticosteroid-Insensitive Inflammation via Reduction of Histone Deacetylase-2 Transcription. The Journal of Biological Chemistry, 284, 36047-36054.

http://dx.doi.org/10.1074/jbc.M109.025387 
Submit or recommend next manuscript to SCIRP and we will provide best service for you:

Accepting pre-submission inquiries through Email, Facebook, LinkedIn, Twitter, etc. A wide selection of journals (inclusive of 9 subjects, more than 200 journals)

Providing 24-hour high-quality service

User-friendly online submission system

Fair and swift peer-review system

Efficient typesetting and proofreading procedure

Display of the result of downloads and visits, as well as the number of cited articles

Maximum dissemination of your research work

Submit your manuscript at: http://papersubmission.scirp.org/

Or contact jct@scirp.org 